\title{
The Saami Shamanic Drum in Rome
}

\author{
By Juha Y. PentikÄINEN
}

Although some of my colleagues, including Professors Gretel H. Pelto and Pertti J. Pelto, suggested that this paper should be written in the form of a science fiction novel rather than that of an article, I opted this time for the latter alternative. This paper was read first as a guest lecture in Rome in October 1982, then at the Nordic Symposium arranged by the Donner Institute in Turku in August 1984 and finally in the city Hall of Patti in Sicily in an Italian-Finnish Colloquium arranged by the Department of Ethnohistory and Anthropology at the University of Palermo, in September 1984. I am thankful to my colleagues on all these occasions for their valuable comments which have benefited the progress of this paper. Without forgetting the others, I would like to remember with deep gratitude the names of Ugo Bianchi, Louise Bäckman, Carl-Martin Edsman, Phebe Fjellström, Rolf Gilberg, Luigi Grottanelli, Mihály Hoppál, Åke Hultkrantz, Rolf Kjellström, Olavi Korhonen, Martti Linkola, Larissa Lomnitz, Romano Mastromattei, Nilla Outakoski, Aurelio Rigoli, Annamaria Savarese. Doctors Marco Curatola and Claudio Cavatrunci, ispettore etnologo, Museo preistorico etnografico L. Pigorini, have opened the doors of the L. Pigorini museum for me and helped me in finding the drum and the documents in Rome. Prof. Patrik Reuterswärd listened to my paper on Saami Shamanism in Åland and sent me information about the Tessin-Cronström correspondence. Anne Helttula has translated the Italian texts, Veikko Anttonen and Kari Vesala have helped in the technical edition of the text and in the bibliography. My heartfelt thanks to all of them.

\section{1. "Lapptrumma" as a diplomatic cargo on early 18 th century}

The turn of the 17th century and the subsequent 18th century were a magnificient period in the history of the Swedish kingdom. Nicodemus Tessin the Younger was the architect of the Royal Palace which was to be built as the symbol of a powerful country for Continental Europe and for succeeding generations. Tessin wanted to build a palace the interior of which would appeal to the continental artistic taste of its period. He was 
creating an appropriately regal setting for the Swedish king, in conformity with leading French standards. In order to keep himself informed about artistic development in Continental Europe, Tessin had an agent in Paris, the Swedish envoy Daniel Cronström who had been the resident at the Court of the French King since 1702 and the Swedish envoy from the year 1703 until his death in Paris in 1719 (Reuterswärd 1966, 265).

Tessin was not, however, only interested in French architecture and art. Fascinated by Roman arts, he also used his agent to get information about Italian culture and such masterpieces as could be used for the interiors of the royal palace and his own house in Stockholm. It was Cronström's task to find the right people and to negotiate with them. Tessin's artistic credo, as becomes apparent from the huge correspondence with Cronström in French from 1693-1718 was "the idea of combining Italianate interiors with interiors decorated and furnished in the French style" (Reuterswärd 1966, 265). It was for this reason that a Lapp drum came to play a crucial role in the diplomatic correspondence between Stockholm and Paris.

Tessin was a good friend of the young Swedish king, Carl Gustaf, and guided his interests in collecting art. It was in 1698 that the name of Callot is mentioned for the first time in correspondence. He later on became Tessin's particular favourite. The king and Tessin wanted to get the complete collection of Callot's engravings to Stockholm. The most important missing Callots were to be acquired directly from Florence, but using Cronström and the Florentine envoy in Paris as intermediary agents. In order to get these valuable masterpieces of Italian art to Stockholm, Tessin used quite a special strategy. He decided to send over to Paris a Lapp drum to be forwarded as a present to the Grand Duke of Tuscany, who then would reward Tessin via Cronström with the desired engravings (Reuterswärd 1966, 265). How everything happened can be read from the correspondence from the years 1705-06 (Weigert \& Hernmarck 1964).

Tessin wrote on January 28th, 1705, about a "lapptrumma" which should be arranged for his use by the governor of Västerbotten, Colonel Gustaf Douglas (1648-1705) to be sent as soon as possible to Cronström for the envoy of Florence:

Au reste, Mr. Douglas come j'espère me faira avoir un "Lapptrumma"l avec ses attributs pour Mr. l'envoyé de Florence, que j'enverroys avec la premiere occasion qui se trouvera ... (Weigert \& Hernmarck 1964, 338).

The first effort to obtain the drum from Lapland did not succeed, however, probably because of the death of Governor Douglas in 1705. Mr. Cronström had accepted the idea and became anxious at his lack of success in his efforts to get the famous Battle of Medici via the Florence envoy to 
Stockholm. He wrote on September 11th of 1705 to Nicodemus Tessin the Younger about his plan to send Mr. Göran Josua Törnqvist, a Swedish architect, as his delegate to Florence to bring back the work in question:

Vous devriez tâcher d'avoir "lapptrumman" [le tambour lappon] par quelque autre. Je mettrois par l'Envoyé de Florence dans son tort de ne m'avoir pas encor donné les battailles de Médicis...

Je tacheroy de faire donner une recomendation à Mr. Törnquist pour Florence par laquelle il pourra obtenir les battailles de Médicis, etc. Si le tambour lappon pouvoit venir incessament, cela y aideroit beaucoup. Mr. Törnquist a dessiné ma grande caléche dans les proportions, je crois que c'est ce qu'il vous fault. Je luy en feroy voir encor quelqu'une plus chargée d'ornements qu'il pourra adjouter par parties (Weigert \& Hernmarck 1964, 346).

The project seemed to proceed when Tessin did get the drum. He wrote to Cronström on February 10th of 1706:

J'ay à la fin eu cette lapptrumma ... (Weigert \& Hernmarck 1964, 351).

\section{Ethical considerations about shipping the Lapp boy to use the drum}

The next step was probably to find out how to use the drum in question. The envoy at Florence was clever enough to make that kind of request, because Tessin wrote to Cronström on March 21st 1706 about his intention to send the description of how to use the drum by the next boat leaving for Rouen:

Depuis, j'ay eu l'honneur de recevoir la vostre du n:o 3 à laquelle ces peu des lignes serviront de response. Je suis très ravy d'apprendre que $\mathrm{Mr}$. l'Envoyé de Toscane vous aye promis de faire venir les 32 pièces de Callot; pour celles de la Terre Sainte, je les ay moy mesme. Mais comme je compte ma caisse de festes perdûe si, au lieu de cela, il y avoit moyen d'avoir l'Entrée de la Duchesse de Lorraine à Florence, cela me fairoit bien du plaisir, car parmy touttes les Entrées c'est le livre le plus rare. J'ay trouvé une description de la manière comme l'on se sert de la machine de Lapponie; j'enverrays l'un et l'autre avec le premier navire qui partira pour Rouen (Weigert \& Hernmarck 1964, 353).

This was not, however, enough. After half a year, the envoy of Florence brought a new request from the Grand Duke of Tuscany. Not only a drum was needed but a lapp boy besides that. Mr. Cronström felt the new request was so difficult that he expressed his opinion quite openly to Tessin at the end of his letter of September 3rd, 1706:

$\mathrm{Au}$ reste, $\mathrm{Mr}$. le Grand Duc est un peu intéressé. Il voudroit plaisir pour plaisir. Il demande un petit garçon lappon et s'offre defaire les frais du voyage. Cette 
commission sera embarassante, dailleurs l'issue en sera reprochable du costé de la religion ... (Weigert \& Hernmarck 1964, 355).

Tessin also felt his situation to be uneasy for several reasons. The surface of the drum had become broken during the transportation process. He did not, however, want to replace the broken cover with a new one but instead sent the drum as it was. The problem of despatching the Lapp boy was even more difficult. He was doubtful of the loyalty of the Lapp race in general, and the religious question seemed overwhelmingly difficult (Weigert \& Hernmarck 1964, 355). A full report of the matter was sent with a delegate from Sweden to France. Tessin wrote on September 19th of 1706:

... Je suis très ravy des estampes de Callot, que Mr. l'envoyé de Toscane vous a livré. Voyla mon oeuvre de Callot tout entier, exceptées quelques peu de feuilles; je vous en suis entièrement redevable.

J'ay envoyé la machine [le tambour lapon] qu'il a souhaitté, telle que je l'ay pû avoir ... La peau du tambour est déchirée en party; il est facile d'en remettre une autre où les mesmes caractères soient imités, mais on ne les estime presque que par leur ancienneté. Ainsy, j'ay crû vous la devoir envoyer telle qu'elle estoit. Pour le garçon qu'on demande, ces gens là sont bien sujects à caution a l'égard de leur fidélité, d'autant plus dans un voyage, ou ils ne scavent s'expliquer envers qui que ce soit, outre les difficultés de la Religion, qui paroissent presque insurmontables. Il en est party un homme d'icy pour la France il y a quelques semaines, qui vous en donnera tout l'eclaircissement (Weigert \& Hernmarck 1964, 355).

In spite of all these problems, the Lapp boy was tracked down and dispatched. He came to Paris before the drum and Mr. Fouquet who was to speak for him. The unhappy Cronström reported his behavior and drinking habits to Tessin on October 24th of 1706:

... Ce Lappon dont voús m'avez parlé est arrivé; c'est un ivrogne dont il n'y a pas plaisir de se mesler. Je le feroy connestre [à] Mr. l'Envoyé de Florence. S'il veut ou peut l'enrôler pour son maistre; qu'il le fasse, c'est son affire ... (Weigert \& Hernmarck 1964, 356).

The letter from Cronström to Tessin of December 10th, 1706 indicates that the drum and Mr. Fouquet had still not arrived in Paris:

Mr. Fouquet n'est point encor arrivé ny le V. qui porte "lapptrumman" (Weigert \& Hernmarck 1964, 366).

The correspondence after this is silent in the matter. The fate of the drum as well as that of the Lapp boy remain uncertain. Tessin, however, did get the engravings he missed, including the Battles of Medicin in copper, which are nowadays in the collections of the National Museum in Stockholm. Tessin could be satisfied, but the problem of the drum remained open. 


\section{The history of the Lapp drum in the museum of L. Pigorini}

I had happily learned of this correspondence before my lecturing tour to Rome in the autumn of 1982. I paid a special visit to the L. Pigorini ethnographical museum located in the E. U. R., the administrative centre in the neighbourhood of Rome built in the style of Mussolini's period of the 1930's. Having read of and heard about this most southerly located Lapp drum, I became greatly surprised on studying the catalogues and indexes of the museum. There was no inventory number for any Lapp drum in the collections of the museum. An Italian scholar was found, however, who had seen the drum some time ago in the storage room of the museum. We were guided there, and finally after a search of a couple of hours, the Lapp drum without no inventory number was found under some Central American ceremonial masks used for an exhibition of the museum. What is the history of that particular drum, which once arrived from the Saami area in northernmost Europe to the collections of an Italian museum? Having the correspondence of the early 18th century in mind, it is necessary to take into consideration the possible connection between the drum of the TessinCronström correspondence and that found in the collections of the $\mathrm{L}$. Pigorini museum. It was in any case a happy accident, that a drum with no inventory number had survived the ravages of war etc. until today.

The Ethnographical Museum in E. U. R. carries the name of its founder, professor Luigi Pigorini. At the time of its foundation in 1876, it mainly consisted of the materials transferred from the Museo Kircheriano, founded by Atanasius Kircher, a Jesuit father, at the beginning of the 18th century. According to the information of Cartella 56 in the historical archives of the Pigorini museum, the drum was donated to Luigi Pigorini by Countess Alomena Borgia, sister of Count Ettore Borgia, on June 10th, 1878. It had been a part of a collection of Scandinavian stone weapons, which had been sold to Pigorini by Ettore and Alomena Borgia in the same year. Professor Pigorini was happy about the donation and sent on the following day (June 11th, 1878) a letter to the Minister of Education with a request to thank Count Borgia for his donation:

Count Ettore Borgia from Velletri has presented this museum with a drum of considerable ethnographical value, made by the Eskimoes or some other nation from those parts. On the leather surface of this drum a reindeer hunt is depicted. Because of the rareness of this article, its great scientific value is due to the scene depicted on it, and the fact that it has belonged to the famous Museo Borgiano of Velletri, which yet increases its value, Count Borgia deserves a word of acknowledgement from you (ASMP 56). 
At first the drum was supposed to be Eskimo, and a place was reserved for it in the collection of Eskimo culture, arranged in Rome with the cooperation of Det Kongl. Ethnographiske Museum in Copenhagen. Pigorini sent an inquiry to Christian Frederik Herbst, a Danish archaeologist, on June 10th, 1878, and received a reply containing the truth about its Lappish origin (ASMP 224). It is probably for this reason, i.e. its non-Eskimo origin, that the drum was left without any inventory number in the collections of the Pigorini museum. Because it could not be part of a greater Eskimo collection, it was left on its own, as the only Lapp item in the museum at that time.

\section{The route of the Lapp drum to the Museum Borgianum at Velletri}

On his Italian trip in 1787 Goethe paid a visit to the small town of Velletri on the road between Rome and Naples, about 40 kilometres from Rome. He there carefully studied the family museum, Museum Borgianum with its "treffliche Altertümer und sonstige Merkwürdigkeiten" (Hildebrand 1937, 112). ${ }^{1}$ The museum, founded at the beginning of the 18 th century, was then taken care of by Cardinal Stefano Borgia (1731-1804). Stefano Borgia had been interested in antiquarian pursuits since his youth. After being nominated to the office of Congregazione de Propaganda Fide, the mission of the Roman Catholic Church in the Vatican, in 1770, he broadened the scope of the family museum to the areas of ethnography and Oriental studies. As the secretary of the office for Propaganda he could combine his museum interests with his church activities. Catholic missionaries all over the world were aware of his interests and did their best to collect materials for him. Stefano Borgia carried on an extensive correspondence with learned people who shared his antiquarian interests (Hildebrand 1937, 112f.).

One of the most active correspondents of Cardinal Stefano Borgia was a Danish theologian Friedrich Münter (1761-1830), a church historian, archaeologist and finally the bishop of Sjaelland. In his youth, Münter studied a whole year (1785-86) in Rome and became a good friend of Stefano Borgia visiting Velletri so often that it became "our museum". The chief of Propaganda had a great influence on the further development of his personality and career. It was Friedrich Münter who worked so hard for the collection of Scandinavian antiquities that the latter became one of the rarities of the Museum Borgianum. Due to this friendship, "grande delizia della sua vita" Stefano Borgia lived on a Danish state pension after being

\footnotetext{
${ }^{1}$ Goethe, W. v., Italienische Reise, note on diary 22.2.1787. 
obliged to flee from Rome for two years during the period of the Roman republic in 1798-1800 (Hildebrand 1937, 116f.).

There is a huge correspondence between Borgia and Münter over the course of twenty years 1785-1804. After having returned to Denmark, Münter worked hard to fulfil the requests of Cardinal Borgia for his Nordic collection, "la classe Boreale" consisting mainly of coins and weapons in stone and bronze. It was Münter's "amica generositá" which increased the Nordic collection. On June 2nd, 1792, Borgia asked Münter to send him a "timpano magico di Lapponia", a Lapp drum which also arrived rather quickly, because Borgia thanked Münter for the beautiful drum which he considered an excellent addition "al Nostro Museo Boreale di Velletri" as early as Sept. 5th 1792. Borgia then had in his museum drums from both Lappland and Greenland, "deus tambours magiques de la Lapponie et du Groenland". In 1795 Borgia wanted to have another Lapp drum, which also was sent by Münter via Brest but was lost or stolen on its way to Velletri (Hildebrand 1937, 120f.). The unhappy Münter wrote to Borgia on December 28th, 1795:

I cannot understand why the case seized by the French has not yet arrived there. Mr. Grouvelle has released it; I suppose it has been caught somewhere else. Its loss would cause me great distress, since I am not able to replace the Lappish troll-drum which is one of the curiosities it contains. But let us hope that it will be found again. I shall speak with Mr. Ramus, who took care of the shipment. Besides, for safety's sake the case was addressed to Mr. Giorgio Z[oëga], not to you (Münter 1944, $136 \mathrm{ff}.)^{2}$

Another great wish expressed by Cardinal Borgia to prof. Münter concerned a runic stone. The first "cippo runico" arrived safely in 1793 (Hildebrand 1937, 131). ${ }^{3}$ Münter was looking for another in 1795-96 and still sorry about the loss of the valuable case.

Cabbot has brought me the description of the Velletri Museum. I wish I could tell you more about the northern things. I am still in search of a runic stone. I have written everywhere and received promises from bishops and clergymen, who are the only ones able to procure them, but have obtained nothing. I am extremely sorry for the case seized at Brest; it will be impossible to get it back from the middle of that disorder. Some of the articles, e.g. the boat from Greenland, can be replaced without great difficulty; but the loss of that Lapp in his sledge, made of the teeth of the sea lion, is irrevocable. It will by now have become the embellishment of some museum at Brest. This is one of the consequences of the war (Münter 1944, 138f.). ${ }^{4}$

The lapp drum sent by Münter to Borgia in 1792 is clearly the drum of the Pigorini museum. When C.V. Hartman, director of the Naturhistoriska

\footnotetext{
${ }^{2}$ Münter to Borgia 28.12.1795.

${ }^{3}$ Borgia to Münter 19.9.1793.

${ }^{4}$ Münter to Borgia 14.12.1796.
} 
Riksmuseets Etnografiska Afdelning in Stockholm made an inquiry about the drum in October 1909, he received the following reply from L. Pigorini:

"Two days ago I sent to your address the two photographs of the Lappish troll-drum kept in this museum. Please accept them as a gift.

The drum belonged to the famous Museo Borgiano [Borgia Museum] founded at Velletri by Cardinal Stefano Borgia in the second half of the 18th century.

When in the first half of the 19th century the Museo Borgiano was bought by the National Museum of Naples, the drum remained in Velletri together with several stone weapons of Scandinavian, perhaps Danish origin.

In $1878 \mathrm{I}$ bought these Scandinavian stone weapons from their owner Count Ettore Borgia for the Museo Preistorico-Etnographico of Rome. On that occasion the Count donated the drum to the museum" (ASMP 56). ${ }^{5}$

The ethnographical collections of the family museum in Velletri were divided between the museums of the Vatican, Florence and Naples. The unique Nordic collection still remained the property of Museum Borgianum until the deal by Luigi Pigorini. After Pigorini had bought the Scandinavian weapons he was donated the Lapp drum which was then transferred from Velletri to Rome.

How and why the drum in question had arrived in Copenhagen, is another question worth studying. At that time, Norway was a part of Denmark (from 1380 to 1814), Copenhagen being the capital of the whole country. Det Kongl. Ethnographiske Museum in Copenhagen became the natural destination of the ethnographical objects found inside the country as well as abroad. Finnmark and Lappmark in the far north were not any more the exotic borders of the territory of the regime but had become areas of general interest, due to the activation of missionary interests in the north.

Thomas von Westen (1682-1727), "the apostle of the Lapps", had in 1716 begun his seminarium lapponicum in Trondheim and launched with his colleagues a strong mission among the Lapps "preaching the gospel, founding schools, building churches and putting missionaries into office". Von Westen himself made three missionary trips to the Lapps (in 1716, 1718-19 and 1722-23) (Reuterskiöld 1910, XII f., 1-7, 12-27).

Under the influence of the wave of witch persecutions from the 16th century onwards, the shamanic drum was considered to be the most crucial manifestation of paganism among the Lapps. A systematic collection of drums took place as a part of missionary work during von Westen's time. According to the information reported by Jan Friis in his Lappisk Mythologi (Friis 1871, 19), a greater collection of drums was sent by von Westen to

\footnotetext{
${ }^{5}$ Pigorini to Hartman 26.10.1909.
} 
Copenhagen where, however, about 70 of them were burned in a fire in 1728. There are six Lappish drums today in the collections of the National Museum in Copenhagen. Two of them are from the period before von Westen's time, i.e. from the 17th century. The two drums sent by professor Münter to Cardinal Borgia in the 1790's may have belonged to the collection of drums found by von Westen or his missionary colleagues and sent from the Norwegian Lappmark to be preserved in Copenhagen. Due to the nature of collecting drums as a part of the Christian mission as well as the fire in Copenhagen, the information about their origins is very deficient as far as the whole Copenhagen collection is concerned.

On basis of the archival information it seems to be clear that the Saami drum in Rome came to the Pigorini Museum from the Museum Borgianum in Velletri. It was shipped to Velletri from Copenhagen by F. Münter in 1792. Münter finally found the drum from the collection slipped by von Westen or his colleagues from the Norwegian Lappmark. Because more precise source information is lacking, the drum must be located on the basis of comparative analysis.

\section{The report of the runebom by Paolo Mantegazza in 1880}

The Saami drum in Rome became familiar to Italian scholars when during the 70th meeting of the Societa Italiana di Antropologia e di Etnologia (April 20th, 1880), Prof. Paolo Mantegazza presented the design of the drum (runebom) and affirmed that, while being the only exemplar in Italy, it was also a rarity in all Europe, since almost all Lappish runeboms had been destroyed in a fire in Copenhagen (Mantegazza 1880, 445).

Paolo Mantegazza was Professor of Anthropology in the University of Florence. In 1880 he published a book Studii antropologici sui Lapponi, with Stephen Sommier as his coauthor, studying the physical anthropology of the Saami. In the following year, 1881, an ethnographical field report "Un viaggio in Lapponia", appeared containing a comparative study of the expressions of shamanism in Greenland and Lappland. Referring to the information by Jan Friis in his Lappisk Mythologi he gives a description of the drum in the Pigorini museum and also describes the use of the drum on the basis of the famous Nærö manuscript in 1723. As an anthropologist, Paolo Mantegazza uses the native terms noaide and runebom quite carefully when referring to Saami shamans and shamanic drums. The concept of runebom stems from texts of Norwegian Lappish origin:

"My dear friend Prof. Pigorini has recently come cross a Lappish troll- 
drum and bought it for the Ethnological museum of Rome. Thanks to his kindness I am able to present here a design of it" (Mantegazza 1880, 284).

The Saami drum in Rome is, of course, a rarity. It is the most southerly located exemplar of the 71 drums, studied by Ernst Manker. At the moment, it is also the only Saami drum the existence of which is certain in Italy. Ernst Manker made an expedition to several Central and Southern European museums in 1932 to trace the possibility of preserved Saami drums. He came to Rome: "The drum preserved in Rome is a very beautiful exemplar" (NM 531, Ms. 22.12.1932). He also tried to find a drum in Florence on the basis of some rumours heard in Stockholm, but without any result. I made similar efforts taking into consideration the correspondence between Tessin and Cronström, but with no results either. It is, of course, possible that the broken drum never reached its Florentine destination, due to the accident with the surface of the drum as well as the problems with the Lapp boy shipped from Sweden to France. Another alternative is that it arrived at Florence, either became lost later on or is still preserved somewhere, for example in a private collection. That Swedish Lappish drum is not, however, the Norwegian Lappish runebom in the Pigorini museum.

\section{Lapp drums as souvenirs and antiquarian objects}

Saami drums were probably popular objects of export in the 17th and 18th centuries. Missionaries and explorers brought dozens of drums from various parts of Lappmark to be sold and shipped to the private collections of noblemen and other interested people all over Continental Europe. Some of these drums later on found their way to the museums, many became lost or are still somewhere, to be traced by future investigations of local museums and private collections.

There is information about five Saami drums which were supposed to have Italy as their destination. The only one preserved is the runebom of the Pigorini museum, the object of this study. Another was sent by prof. Münter to Cardinal Borgia in 1795-96 but was lost or stolen at Brest. The third drum was the diplomatic cargo from Västerbotten Lappmark to be shipped from Stockholm by Tessin the Younger to go via Rouen and Paris to Florence in 1705-06 (Reuterswärd 1966, 266). Besides these three drums, there is literary evidence of two others which arrived in Italy at the end of the 17th century. An illustration of a drum with a hammer and a ring was published in a posthumous work by Francesco Negri of Ravenna, Viaggio 
Settentrionale Fatto, in 1701. It is highly reminiscent of the drawings published by Joh. Schefferus in his Lapponia of 1673.

Schefferus's Lapponia had a great influence in awakening general interest towards the Lapps in the 17th century. It was a kind of bestseller of the period, appearing in the course of ten years in five different languages covering the whole of contemporary civilized Europe: Latin 1673, English 1674, German 1675, French 1678, Dutch 1682. This book was certainly much better known in Continental Europe than in Scandinavia itself. It gave its international readers valuable information about the way of life and religion of this people, considered the most exotic in the whole of Europe, in spite of the fact that Schefferus in his Lapponia used no eastern Lappish source.

A typical example of this interest is a letter sent by Mr. Magalotti to Joh. Schefferus in September, 1674. Magalotti worked as the agent of the Grand Duke of Tuscany in Stockholm to get a complete curiosum from Lappland shipped to Italy. Beside the collection of Lappish costumes, he already had a drum with a hammer. What he particularly needed in this respect were rings to jump on the surface of the drum and a storjunkare, the image of a Saami god:

\section{Monsieur,}

Your kindness of which you have given me ample proof since I first had the pleasure of meeting you, and the openness with which you have shown me that you wished to continue henceforth in the same mind, give me the courage to remind you today of the favour for which you had allowed me to hope, that you would undertake to assemble a collection of curiosa which as far as possible would resemble your own. The honour in which you are held by my noble lord, the Grand Duke of Tuscany, is well worthy of this correspondence from you, since it is at his request that I feel obliged to make this entreaty. Whatever you collect in the course of time may be delivered to Herr Nicolas Matthiessen, German merchant, resident in this city by the German Church. I also authorise him to pay the sums of money you require when you deliver any curiosum to him. If something of particular value should arise, I beg you to inform me in advance, which you may do by addressing any letters intended for me to the above mentioned merchant. The journey you will understake to the North will thus offer you a favourable opportunity for the acquisition of some curiosa from Lapland. What I already have of such items is: their dress, boots, shoes, gloves, feather cap—all embroidered with lead. You need not therefore trouble yourself with anything of this kind. I also have a drum and a hammer. What I would like is one of the rings which they make jump on the drum when they hit it, a bow, some arrows of their own manufacture and above all a pair of skis. I would also be very happy to acquire a storjunkare together with anything there is which could serve science, with the exception of copper and silver coins, of which I am sufficiently provided. You see therefore how I impose on you, although you give me all too little reason for this, as you have forgotten, in the catalogue you had the kindness to send me of your works, to give the title of the book you would 
so like to receive. I beg you not to forget it this time, and I am quite convinced that there can hardly be anyone in this world who appreciates your worthiness as much as my Master.

Messrs. Åkerman and Schefferus are hereby assured of the deepest devotion of their most humble servant,

Magalotti

Stockholm, 11/1 September 1674 (UUB G 260c, 57). ${ }^{6}$

Interestingly enough, Tessin the Younger worked three decades later to send a Saami drum to the same destination as Magalotti: the Grand Duke of Tuscany in Florence. The drum sent by Tessin cannot be the same, because it was arranged for this purpose via the governor of Västerbotten in 1705 . Magalotti wrote in 1674 that he already had a drum with a hammer. It is even possible that there are two different Saami drums somewhere in Florence, one sent by Magalotti, another by Tessin. Anyhow, Reuterskiöld is wrong to assume that the drum in Rome (published by him on the basis of Mantegazza's book) is the same as the one reported by Magalotti. Magalotti's unknown drum came from Swedish Lappmark in the 17th century, the runebom in the Pigorini museum reported by Mantegazza is Norwegian Lappish and from the early 18th century (Manker 1938, $737 \mathrm{ff}$.).

Why did the royal architect, Tessin the Younger, choose a Lappish drum as his diplomatic cargo to obtain the desired engravings from Florence? He, of course, must have been aware of the great interest of the Grand Duke of Tuscany for Lappish antiquities, particularly the shamanic equipment. Stockholm was a continental city where envoys and agents met as well as in Paris. Although Tessin the Younger may have been ignorant as far as the letter from Magalotti to Schefferus is concerned, he was certainly clever and interested enough to get to know the oral histories, one generation old at that time and surely remembered in learned, artistic circles of Stockholm. When planning his manoeuvre, Tessin the Younger could be almost sure about his success as actually happened.

There clearly has been a special interest towards the most northern corner of the European continent in the Mediterranean countries, particularly in Italy. This interest also led to such important excursions as those by Giuseppe Acerbi and Paolo Mantegazza and so on. The correspondence and other descriptions quoted above bear evidence about shamanism as the most illuminating and appealing manifestation of the ancient culture and religion of the exotic people living behind the circumpolar zone at the edge of the universe. Shamanism has always been one of the favourite objects

\footnotetext{
${ }^{6}$ Magalotti to Schefferus 11.9.1674.
} 
described by scholars studying the most northern territory in Europe. There seems to have been some appeal towards exotic people in the north shared by Italian scholars and vice versa. Why not mutual interest from the North towards the south, for example in the way expressed by the most popular Finnish Christmas song, "Sylvia's Christmas Song"' with its Sicilian nostalgic dreams.

\section{The cosmology of the drum}

Paolo Mantegazza was the first scholar to give his interpretation to the figures on the surface of the drum. As an anthropologist he was able to realize that the three items preserved, the drum itself, the hammer (coarvevaever) as well as the ring (vuorbe or vaeiko) formed a whole:

"The coarve-vaever was a T-shaped wand made of reindeer horn, sometimes covered with leather, with which the drum was beaten. The vuorbe was either a brass ring from which other small rings were hanging, or a triangle made of bone. It represented the sun, and when the runebom was consulted the ring or the triangle was placed on the figure of the sun designed in the centre of the drum (Mantegazza 1881, 284f.).

Mantegazza's important discovery was that each piece of equipment played its own role as a part of the shamanic session which should be interpreted holistically. He did, however, forget to explain what was behind the beautiful surface of the drum.

Nordic research on the drums has hitherto been mainly typological inventory. Reuterskiöld began the historical tradition followed by Wiklund and Manker, The Saami drum in Rome was familiar to all of them on the basis of Mantegazza's book as well as the correspondence between Pigorini and Hartman. Wiklund made a typological survey on the drums, defining the drum in Rome as the manifestation of the socalled Ranentyp (Wiklund 1930, 96). Manker mainly agreed with him but supposed that the place of origin might be farther north because the hunter of the drum had a Kautokeino hat. As fas as its construction is concerned the drum in Rome belongs to the category of Schalentrommel (NM 531, Ms. for Manker 1950; Manker $1938,741 \mathrm{f}$.).

The sum of the technical details of the drum is quoted according to the inventory by Ernst Manker:

"In this drum too the part indicating heaven is separated from the earth, and you can see the figures of the gods, the sun, the house of the Christians, the reindeer and the bear. The design also includes the magic wand, which, however, is made of wood, not of reindeer horn" (Manker 1950, 390 ff.).

Mantegazza realized that the part indicating heaven on the surface of the 
drum has been separated from the earth. Manker also divides the figures of the drum into two: the 11 figures belonging to the upper region and the 9 of the lower region. The clear centre of the drum, however, is the sun which again has a black centre. The peive or the sun seems to be under the celestial sphere, although connected by a line up to the radial line between heaven and earth, on the one hand, and with a thicker pillar down to another line towards the bottom of the drum, on the other.

This drum is very sun-centred. The peive is a part of the pillar of the universe around which everything takes place both in the heaven of the deities as well as among people below. The line under the pillar indicates the fine borderline between the spheres of the living and the dead members of the family or the clan, i.e. the thin boundary between life and death, this world and Jabmeaivo, the Land of the Dead where everything is upsidedown compared to this world. An ordinary man could wander there in his dreams or supernatural experiences with the stallo, the qufittar and the other beings of that sphere (Nielsen 1934, 379; Turi 1910, 200-206; Pentikäinen 1984). The surface of the drum may be divided into three realms of the universe than rather into two as research sofar has interpreted it.

What becomes manifest on the surface of the drum is a Saami Weltanschauung of a tripartite universe. It consists of the upper realm of the heavenly deities, the middle human realm and the lower realm, Jabmeaivo or the world upside-down. They are, however, connected with a pillar having a peive or the sun as its centre. The sun is located in the centre of the whole drum surrounded by gods, people, animals and other symbols in a symmetric configuration towards the centre. The location of the figures as well as the whole stucture of the drum with its oval form seems to indicate a cyclic view of life.

The Saami way of life, economy and culture is highly dependent on the sun. Seasonal variation is felt very strongly in the Arctic and Subarctic conditions of the Far North. In winter there is a long kaamos period with no sunrise and in summer a couple of months with no sunset. Most of the Saamis have until recently been nomadic or seminomadic people moving annually from place to place in accordance with the migratory drive of the animals (moose, elk, deer, reindeer, salmon, trout) they have been hunting, fishing or breeding. After settling down, the Saamis have often occupied summer and winter villages or even summer, autumn, winter and spring cabins for the different branches of their combined economy system. The Saamis have, for this reason, been called "the people of eight seasons" (Manker 1963).

In northern Fennoscandia, the Saamis have occupied a huge area from Central Scandinavia (the most southern corner being in Idre in Dalarna) to 
Finnmark and the Kola Peninsula on the coast of the Arctic Ocean. The dates of the eight seasons, of course, vary from area to area and are highly dependent on the resources of each Saami group and their economy and culture. In Swedish Lappland between the Pite and Tornio rivers the seasons follow one another roughly as follows: winter lasts from December to March, early spring is March-April, spring May-June, early summer in June, summer in July and early August, late summer in the end of August, autumn in September-October, late autumn in November. Seasonal rotation is taken into consideration annually when moving from one landmark to another, starting and finishing seasonal activities in fishing, hunting, reindeer husbandry, berry picking and so on. Social, cultural, religious and private life also followed the annual rhythm of the seasons to such an extent that courtship took place in early summer and almost all childbirths occurred in late winter. The religious calender, of course, was obliged to adapt itself to this seasonal rotation. It brought some kind of functional rhythm into the routines of daily activities and social life. The high seasons of religious life followed observations of the sun. From this point of view, time was not considered as linear but cyclic. The winter period started from the 14th October and summer period from the 14th April. The day of kaskatalve (Midwinter) was on January 13th and that of kaskakesse (Midsummer) on July 13th. A year could be divided into two parts, into winter and summer. As far as economy and culture is concerned, it is possible to speak of winter and summer cultures among the Saamis (Aikio et al. 1985; Manker 1953, 23-40). It is only natural that this division particularly concerns religious affairs both in Pre-Christian and Christian times. For example, the Laestadian service calendar knows winter and summer services, the high seasons being around the dates of Midwinter and Midsummer.

Shamanism is one of the main manifestations of Saami Pre-Christian religion, and many of its functions have remained as a part of Saami world view until recently in spite of the fact that almost all the Saami are at least formally baptized Christians nowadays. The natural centre of the drum is the sun. This does not, however, mean that the Saami had worshipped the sun god, as has been supposed by some scholars until now. The more probable interpretation is that the drum has been read and interpreted in a perennially varied way, due to the season, person and problem in question. The oval form of the drum and the location of the figures towards the heliocentric sun indicate the same. The director of the shamanistic session, the noaide or the shaman was an expert in shamanic folklore. He had to know the myths about the origins of the universe as well as the culture. Mythic time is cyclic. The early golden times are brought to the present every time that a social, cultural or private crisis takes place. 
The drum is a key to the cosmology of the Saamis. The shaman had an intimate relationship with his own drum which was often also made by him. The figures of the drum were a kind of cognitive map for the trip of the shaman's ego-soul between the three levels of the universe. At the same time it was the collective side of the drum, open to the public to be observed collectively and interpreted publicly by the shaman to the audience who shared the same cosmologic beliefs. The cyclic world-outlook of shamanism became manifest in the oval shape and the heliocentric figures of the drum. It was probably used, read and interpreted from different directions in a way that shifted annually in accordance with the seasonal variation.

\section{The use of the drum in the shamanistic seance}

Paolo Mantegazza gave a description of the use of the drum on the basis of the Naerø manuscript of 1723 . Because it very probably stems, both in space and time from approximately the same cultural area as the runebom of the Pigorini museum, it is quoted below in extenso:

To ask advice before any undertaking of some importance (a journey, a hunting or fishing trip) or in a case of illness, the Lapp consulted the runebom. It seems that every family had one, just as every Protestant family has a Bible. Only in the case of more serious matters the noiade was asked to act as an intermediary; normally the runebom was consulted by the head of the family. After numerous preparations and gesticulations the vuorbe (the ring) was placed on the drum, which was then beaten with the wand until the bouncing ring finally stopped on some figure and refused to move away from it. The place where the ring had stopped revealed the will of the gods. If a journey was planned, the stopping of the ring on the sign of the morning or the evening indicated the time in which one had to set out. The ring which stopped in that part of the drum where a lek with fish was designed promised success for a fishing trip. If the ring stopped on the edge of that part, the god of the fishes would be propitious if he received an offering; but if it refused to enter into that part of the drum, no success could be expected. The runebom had a place of its own in the special sacred part of the hut. At the risk of death of some other great disaster no woman was allowed to touch it or even walk on the road along which the drum had been carried (Mantegazza 1881, $285 \mathrm{ff}$.).

A Lapp named Andreas Livortsen had an only son aged 20, who was so ill that nobody believed he would recover. The desperate father used all the runerie or magic arts he knew, but all in vain. Finally he decided to turn to the runebom. He was a great noaide himself, but according to the articles of his faith in such a very personal matter he was not allowed to consult the runebom himself. Therefore he sent for the brother of his late wife; this man was as capable as the father himself in the arts of the noiades. After the opening ceremonies the brother-in-law placed the ring in the right place and 
began to beat the runebom with the hammer. But look! The ring went straight away to the jabmicuci-balges, the road of the dead, quite close to the kingdom of the dead. The father was very upset, especially when he saw that although the drum was beaten harder and harder, accompanied by all kinds of incantations, the ring refused to move away from there; at last, advised by his brother-in-law, the father promised to sacrifice a female reindeer to the dead. Then at last, when the runebom as beaten again, the ring moved but did not go any further than the road of the Christians, wherefore the brother-in-law beat the drum again. But now the ring went back to the road of the dead. This time the father promised a male reindeer to Mubben-aibmo (Satan), in order to make his son live. The ring moved, but went again to the road of the Christians, and it was impossible to make it move into that part of the runebom where the huts of the Lapps are (which would have been a certain sign of recovery). The brother-in-law beat the drum the third time, with many exorcisms, but the ring went back to its earlier place, i.e. the road of the dead, and stayed there, until the father, in addition to the two reindeer, promised to sacrifice a horse to the noiade of the reign of the dead, if he runed in such a way that the dead would allow the ring to go to the Lappish huts, and so the father could be sure that his son would live. But this time even less was achieved than before: in spite of all the beating, the ring stayed still on the road of the dead; therefore a certain death was predicted for the young man. The brother-in-law was amazed and could not understand why the ring gave a worse prediction and the gods remained more inexorable after receiving such offerings. Finally he took the following measures: he went down to the shore and picked up an oblonged stone. Having consecrated this stone with many exorcisms and incantations, he hung it in front of the hut; then he threw himself in front of it, face against the ground, and said a prayer; he then asked Mubben-aibmo (Satan) the reason why the ring refused to abandon the road of the dead, although such splendid gifts had been promised to him, to the dead and to the noiades of the reign of the dead. He then heard the son give this answer: the promised offerings had to be sacrificed to him and to the other gods immediately, otherwise the boy would die, unless another human life could be offered instead. These were hard conditions; it was impossible for the father to fulfil his promises as promptly as Satan demanded, having at hand neither the reindeer nor the horse he had promised; and where could he find a man ready to offer his own life to save his son? Therefore, if the father wanted his son to live, he had no other way than die himself; and he willingly decided to do so. And as soon as he had made this decision, with which he showed a greater love for his son than for his own soul, the brother-in-law returned to beat the drum again, on which the ring was still 
in its first place; but now it moved and went onto the Lappish hut, which predicted life and health to the sick person. The strangest thing is that immediately the son began to feel better, while at the same time the father fell mortally ill, and after dinner the following day the son was completely recovered, at the very same moment when his father, dying a miserable death, gave his miserable soul to the devil.

The son showed his gratitude to his father, according to the wish he had expressed at his last moment, by sacrificing a male reindeer to his soul; so he could more comfortably move around and go where he wanted to in the reign of the dead.

This Lapp named Johan, to whom all this happened five years ago and who is now in service in my parish in Helgeland, has told this story, together with other Lapps and their wives, in my presence in my house in the January of the present year 1723 (Mantegazza 1881, $287 \mathrm{ff}$.) $)^{7}$

Mantegazza's information coincides with the other sources from the same era and from the same cultural area. The shamanic session varied according to season and reason, for example, when and why it was arranged, for whom, by whom and for what particular purpose. The drum must be regarded only as a part of the whole including the other ritual repertoire and all the other attributes of the shaman in his culture. The drum clearly had both the collective side, drawn or painted on the skin surface, read and interpreted publicly for the audience and the more private backside.

\section{The family side of the drum}

Research has hitherto only been interested in the collective front of the drum and almost completely forgotten the inventory of the back side. Also in the case of the runebom in Rome, there is a complicated symbolism in the under side which does not only indicate the artistic values of the drum maker but may contain clues for dating and locating the drum. The figures cut with a knife on the nether side are symmetric and may refer to reindeer marks or to more esoteric information transmitted in a clan or a family from generation to generation or even as a sacred tradition passed from shaman to shaman in succession. In order to be sure about the meanings of the symbols on the lower side, all the known drums should be revisited and restudied. This type of holistic analysis-a research project under planning process-will surely lead to a new interpretation of the semiotics of the uses, meanings and functions of the Saami shamanic drums.

\footnotetext{
${ }^{7}$ Ms. of Naerø $11 \mathrm{ff}$. Cited in Mantegazza 1881, $287 \mathrm{ff}$.
} 
The huge body of information on Arctic shamanism seems to agree in regarding shamanism as a clan or family institution (cf. Shamanism 1978; and Shamanism 1984). The shaman often acted on behalf of his kin against competing groups, peoples, clans, families etc. Shamanism was still a family institution when Thomas von Westen in the 1710's and 1720's was collecting tens of drums from the Norwegian Lapps-one of which probably is our runebom in Rome. A Soviet ethnographer S. I. Weinstein reports that the Tuva in Central Siberia, 30.000 in all, still had in the 1930's as many as 700 shamans (Weinstein 1984, 353).

Although the use of the shaman drum later on was usually confined to one leading regional shaman, it was not unusual for the head of a Saami household, siita, to use the drum in simple exercises of divination. Holding the drum in his left hand and the drumstick in his right, he would place a small object, called an arpa (or triangular piece of reindeer bone decorated with metal rings and ornaments) on the face of the drum and follow its movement on the drum's face. He might predict a number of things on the basis of this act. He might decide, for example, in what direction his siita should continue on a migratory journey; where he might find a lost reindeer or a grazing spot for his herd; what courses of action he should take to protect his clan from beasts of prey; where the best hunting spots were; when it would be best to depart on a journey he was about to take; what sacrifices he had to offer to the gods or guardian spirits to protect the victim of a serious accident, and so forth. The drum was also used to determine the will of the gods for punishment of reindeer theft, murder, and other crimes (Harva 1915, $100 \mathrm{ff}$; Collinder 1949, 148).

There were also special norms connected with the drum itself. Here, it is important to note that among the Saamis, the use of the shaman drum was taboo for women. Documentary sources of the seventeenth and eightheenth centuries concur that women were not even allowed to touch it (Itkonen 1948, 2, 33). The drum was stored in the rear part of the so-called boasso, the holy corner where no woman could set foot. Rehn tells, for instance, that when on migratory journeys, the Saamis first took the shaman drum to the new location. This practice was based on the belief that if a woman even came into contact with a drum harm would come to her. According to Rehn, women were not allowed to follow the path by which the family's man had taken the drum to its new place of storage for three days. On seasonal journeys, the drum might also be placed in the last sledge of a moving caravan, or was sometimes taken to its destination along a completely different path (Cf. Manker 1938, 23-73). This kind of information coincides with the general view of Saami shamanism as a male institution. 


\section{The problem of the hunter with}

\section{a Kautokeino hat in heavenly sphere}

There is a problematic figure in the celestial sphere of the runebom in Rome. Above the traditional pictures indicating the heavenly deities of the Saamis (Väraldenolmai, Bieggolmai, Tiermes or Horagalles and Leibolmai) there is the figure of a hunter with a four-edged hat on his head and a bow and an arrow in his hand towards a bear under a picture of a large reindeer with great horns. It was on the basis of this so-called Kautokeino hat, that Manker located the drum's origin as Norwegian Finnmark (Manker 1950, $390 \mathrm{ff}$; cf. Wiklund 1930, 96). This kind of hypothesis, however, quite contradicts the theory of some ethnologists, according to which this kind of Kautokeino hat is very recent among the Lapps in Finnmark. It became a fashion among the Lapps from the 19th century at the earliest (Itkonen $1948,1,363$ f.). ${ }^{8}$ For this reason, some scholars suggest that the whole drum is not at all authentic or that the peculiar celestial sphere had been made at a later date when the drum had been repainted for some reason. Other scholars consider it authentic and-on the basis of comparative analysis -located it either in Pite or Lule Lappmark, on the Norwegian side.

My own study indicates the latter opinion. There is no sign of any repainting on the surface of the drum. The whole skin was painted at the same time. In accordance with the historical documents, we come to the following conclusion: the drum was found during the mission of the 1710's or 1720's by von Westen or his colleagues but was probably painted as early as the second half of the 17th century in Pite or Lule Lappmark by the Lapps who moved over the Swedish-Norwegian border.

The runebom in Rome seems to reflect a world view of hunters. There is one bow and arrow in the human sphere and one hunter in heaven. But what special purpose has the hunter in the celestial sphere, above the heavenly deities? His picture has been painted quite naturally. Compared to the bear, his size seems to be quite natural. The figure of the reindeer, on the contrary, is magnificient and gigantic, compared to both the hunter and the bear. This may also be the clue to the solution of the problem of the hunting drama in heaven. It may not concern an ordinary hunting episode here but an astral hunting drama above in Heaven. The hunter may be a shaman. If this type of a four-edged Kautokeino hat became a fashion as late as the 19th century, it may well have been a part of the repertoire of the shaman, his former ceremonial hat. This may also be the reason why the church authorities particularly attacked this kind of hat rather than other

\footnotetext{
${ }^{8}$ I am thankful to Martti Linkola for his comment in the conference in Turku 1984.
} 
quite decorated Saami costumes. The four edges of the hat may indicate the power of the shaman as the mediator between this world and the other. In this role he had the capacity to rule over the four corners of the universe, east, north, west and south as well as the seasons, spring, summer, autumn and winter.

A comparison can be made here between Saami shamanism and Finnish folklore, on one hand, and with Siberian shamanism, on the other. As has been said above, in Saami shamanism the shaman drum clearly reflects the view of the universe forming three zones. On the basis of the Finnish creation rune, the cosmos is similarly divided into the upper, middle and nether spheres (Pentikäinen 1987 a.). The centre of this world view is the sun, in Lappish peive, or the Tree of Life. The Evenks and some other Northeastern Siberian peoples describe the roots of this life tree as being the cosmic rivers of the shamans themselves. There is a Land of the Dead in the mouth of each river where the shaman journeys during his trip to meet his helping spirits, i.e. among the dead. The hole, often drawn concretely on the surface of the Lappish drum, is the manifestation of the outstanding capacity of the shaman to wander from zone to zone and to interact with the deities and the spirits of each zone where necessary. $\mathrm{He}$ was considered to be the real mediator of the universe. The shaman's dress refers to the same fact. V. Basilov tells about the Evenks of the Baikal Lake who had two kinds of dress, that of a bird for the upper and that of the ox for the nether world. The Selkup used the dress of the wild deer when journeying up, and that of the big bear when going down to the nether world. Sometimes the same shaman had two drums, one for his journey up, another down to the Land of the Dead. It is interesting that the ritual actions also varied according to the destination of the trip of the shaman's soul. Such shamanistic attrributes as a snare or stack referred to the heavenly trip, fish figures down to the Land of the Dead (Basilov 1986).

In Finnish poetry, the rune on the Skiing down the Hiisi Elk seems to be a description of the heavenly journey of a shaman, Lemminkäinen. The elk has been born in the astral hemisphere. The skiing takes place in the same cosmic zone, when going up Tapomäki, climbing Kirjovuori, i.e. the level of the heaven of the Milky Way. Päivölä, the Land of päivä, aurinko, Sun, where the banquet of gods takes place is not in Hell but in Heaven. Later folklore has moved this meeting place from the heavenly atmosphere to the black river of Tuonela, the land of the Dead. It was there the dead Lemminkäinen was finally found by his mother. In spite of his effort to go up, Lemminkäinen's destiny is to die, to go to the land of the dead, called Manala or Tuonela in Finnish folklore. He joins the group of cultural heroes who shared the rare experience of having visited the land of the dead, 
forbidden to ordinary people but the destination of most shamanistic trips (Pentikäinen 1987b). According to Mythologia Fennica by Christfried Ganander, in 1785, the expression "Tuonella käydä, Tuonelassa vaeltaa", 'to visit Tuoni, to wander in Tuonela' mean falling into an ecstasy or trance (Ganander 1960, 94). The hostess of Tuonela is described as a feminine figure, the virgin of Tuoni, the girl of pains who welcomes newcomers at the river of death. Väinämöinen makes his trip in the shape of a snake to get through the iron net to hinder his departure.

A notice should be taken in the petroglyphs of the large size of the elk or deer. At the Onega and Uiku River fields in Onega and White Sea Karelia for example, reindeer can be three meters in size. The giant figures of the large deer are reminiscent of the folk poem about the Great Ox, which doesn't necessarily refer to the bovines of farming culture and can just as well refer to the elk, whose "head swings in Häme (Taastia) tail hangs in Tornio". According to Matti Kuusi (Kuusi 1963, 164), the great ox is related to the killing myth of the great bear like the birth of the bear. Already in his writings of the 1960's Kuusi sought connections between the poems and petroglyphs. Julius Krohn showed the great ox to be the counterpart of the Siberian blue ox, whose "stomach drags along the ground, horns pierce the clouds" (Krohn 1885).

The scholar of Siberian rock art, Okladnikov, has related the subject matter to northern Euroasian folk tradition. Some Siberian peoples see the Big Dipper, known to Uralic peoples as the Great Bear, Otava, as an elk constellation and its three stars as hunters. The mythical mandas' deer of the Kola Lapps also belongs to this subject matter. In referring to the Domi petroglyphs, Okladnikov hypothesizes that the boat points to the area where the reindeer or elk descends into the Tuonela River to rise again the next morning into the heavens gold-horned (cf. Autio 1983, 135f.). The poem Pilvivene, cloud boat, is related to this subject matter which, according to Matti Kuusi, is part of cosmic mythology (Kuusi 1963, 197):

In the boat are three men

What are they doing there;

Currying the Hiisi elk

Washing the reindeer

They got the elk curried

The reindeer washed

It ran there, the Hiisi elk

Gathered, the reindeer

Where vipers drink beer

Snakes draw near (Lönnrot 1829-31, 1, 26).

The sun, to which the elk and the boat are obviously related, is worthy of note when examining the Astuvansalmi field of pictographs in southern 
Savo. In 1985 I spent a day at Astuvansalmi and was able to follow how the painting area grew visible in a varying manner as the sun casts its light on the paintings done in red clay. The location of the Astuvansalmi boulder in an east-west direction on the north side of Yövesi corresponds to the painted boulders at Hossa in Kainuu in Northeastern Finland. Both are visible in the setting sun then, when night and day compete with each other, that is, when winter becomes summer and vice versa. In examining the Astuvansalmi painting area, it was easy to observe how these first hand observations were dependent on the movement of the sun. Their world view is cyclic and time mythical, becoming manifest in the course of the rituals acted annually by hunters in accordance with the mythical model painted in ancient pictographs.

\section{Shamanism and totemism}

The heavenly hunter may thus be the Saami "brother" of Lemminkäinen in Finnish folklore and the male figures of Finnish pictographs or Siberian petroglyphs. The hunter of the drum is in the company of a gigantic reindeer. The celestial bear may also be connected with totemistic myths describing the origin of a clan which should be in the primordial relationship between the grandparent and a bear. This bear is not an ordinary animal but the celestial Big Bear, Otava in Finnish. Saami folklore knows totemistic mythology both about wild or reindeer and bear as alternative totemistic animals. Vladimir Basilov has emphasized that the innermost part of the drum is its nether side, according to Siberian shamanistic folklore. The drum has often been identified as being an animal, an elk or a horse that the shaman used when riding on his cosmic road. The shaman had an intimate relationship with his drum. It was like his own maternal ancestor as an animal, the representative of the animal species considered to be the totem of a particular people or clan (Basilov 1986). The trip of the shaman to the other world took place in the shape of that animal when he was riding the drum as if it were that animal and were going to meet that Protoanimal in the Land of the dead in the same way Väinämöinen went to meet the protoshaman Antero Vipunen.

In the old religion of the Saamis, shamanism was a family or clan institution having many important social and religious functions. In his various roles, the noaide was an important link between the different levels of the universe. Typically enough, there are holes or treshholds drawn on the surface of some drums between the upper, middle and lower sections of the drums. The shaman was supposed to be able to make ascents and distincts from one realm to another in the universe. He was a necessary 
mediator between man and the cosmos, having a tripartite structure. From this point of view, a Lapp kota with its seven corners may be considered as a manifestation of the Saami world view. It is a kind of microcosmos of Saami social life as family and clan. The boasso was the holy corner, the sacred place of the drum. The main pole of the kota kept its structure together, but was, at the same time, the manifestation of the structure of the universe centred around the Northern Star and the Milky Way. A Saami nomadic family, living in this kota, could observe the movements of the stars, the northern lights and the other phenomena of the skies through the smoke hole around the main pole at the roof of the kota. It was quite natural that people strongly felt that their microcosmos was a part of Nature, the macrocosmos. The drum in the boasso, used by their religious leader in certain ritual contexts, made it possible to overcome the boundaries of human existence. When conflicts arose or diseases or accidents occurred the necessary harmony could be reached by shamans as mediators between man and universe. For this reason, shamanism, although modified, plays its special role in current Saami world views. Maybe it is a kind of manifestation of in illo tempore, the premordial state which must be reexperienced when severe times of minority oppression occur (Pentikäinen 1984).

Paolo Mantegazza concludes his study as follows:

The runeboms are not all equal, even if they have much in common. In some of them almost all the figures are taken from Christian beliefs; these drums have probably belonged to Lapps who were officially Christians, but who secretly continued to observe their pagan practices. Nowadays the gobda (runebom) is completely unknown among the Lapps; they do not even know its name any longer. The Lapps were famous for their magic arts among their neighbours, the Finns.

Finally, he makes a comparison between the Saami drum, the gobda and the Sampo of Finnish folklore:

Many explanations have been given of the sampo, the miraculous implement celebrated in various songs of the Finnish Kalevala and made by the Finnish hero Ilmarinen in order to win the most beautiful girl in Pohjola (Lapland), the daughter of Lochis (Mantegazza 1881, 290ff.).

Friis supposes that Sampo was nothing else than a gobda or runebom (Friis 1871, 47-52). Without taking the whole problem of the Sampo into consideration, the runebom in Rome seems to support the idea of the Sampo as the pillar of the universe. There is a clear pillar of the universe in the drum having the peive or the sun as its centre. Inside the sun there is a deep hole or a black centre which is the road of the shaman into the inner depths of the universe and into the human mind. Peter Hajdú has connected the Sampo with the Tungus concept of the shaman and the Sanskrit Soma 
(Hajdú 1963, $169 \mathrm{ff}$.). The Sampo issue is, however, much more complicated than Friis and Mantegazza suppose and demands a separate study.

\section{Bibliography}

UNPUBLISHED SOURCES AND LITERATURE

Rome

ASMP L'archivo Storico del Museo L. Pigorini

Folder 56

Folder 224

Stockholm

NM Nordiska museet

Lapska avdelningen

531, Ms. 22.12.1932.

531, Ms. for Manker 1950.

Uppsala

UUB Uppsala universitetsbibliotek

G $260 \mathrm{c}$

\section{PUBLISHED SOURCES AND LITERATURE}

Aikio, P. et al. 1985. The Saami people in Finland. Cultural minorities in Finland. Ed. by J. Pentikäinen \& V. Anttonen. Helsinki.

Autio, E. 1983. Astuvansalmen kalliokuvien uusi tulkinta. Kotiseutu 3.

Basilov, V. N. 1986. The shaman drum among the peoples of Northern Europe and Siberia Traces of the Central Asian culture in the North. (Publications of the Finno-Ugric Society.) Helsinki.

Collinder, B. 1949. The Lapps. New York.

Friis, J. A. 1871. Lappisk Mythologi, Eventyr og Folkesagn. Christiania.

Ganander, C. 1960. Mythologia Fennica. Helsinki.

Hajdú, P. 1963. Von der Klassifikation der samojedischen Schamanen. Glaubenswelt und Folklore der sibirischen Völker. Ed. by V. Diószegi. Budapest.

Hildebrandt, B. 1937. Kardinal Stefano Borgia och Sverige. Lychnos.

[Harva], U. 1915. Lappalaisten uskonto. [By] U. Holmberg. (Suomen suvun uskonnot 2.) Porvoo.

Itkonen, T. I. 1948. Suomen lappalaiset vuoteen 1945 1-2. Helsinki.

Krohn, J. 1885. Kalevala. (Suomen kirjallisuuden historia 1.) Helsinki.

Kuusi, M. 1963. Kirjoittamaton kirjallisuus. Suomen kirjallisuus 1. Helsinki.

Lönnrot, E. 1829-31. Kantele taikka Suomen Kansan sekä Wanhoja että Nykysempiä Lauluja 1-4. Helsinki.

Manker, E. 1938. Die lappische Zaubertrommel 1. (Acta Lapponica 1.) Stockholm.

- 1950. Die lappische Zaubertrommel 2. (Acta Lapponica 6.) Stockholm.

- 1953. The nomadism of the Swedish mountain Lapps. (Acta Lapponica 7.) Stockholm.

- 1963. De åtta årstidernas folk. Göteborg.

Mantegazza, P. 1880. Tamburo magico lappone. (Rendiconti della Societa Italiana di Antropologia e di Etnologia, Archivio per l'antropologia e la etnologia 10, 455.) 
- 1881. Un viaggio in Lapponia. Milano.

Münter, F. 1944. Mindeskrift 5. Kopenhagen \& Leipzig.

Negri, F. 1700. Viaggio settentrionale. Padova.

Nielsen, K. 1934. Lappisk ordbok 2. Oslo.

Pentikäinen, J. 1984. The Saami shaman. Shamanism in Eurasia. Ed. by M. Hoppál. Göttingen.

- 1986 a. The background to the Finnish creation myth. Traces of Central Asian culture in the North. (Publications of the Finno-Ugric Society.) Helsinki.

- 1987 b. Lemminkäinen-shaman or God? Finno-Ugric world-view, folklore and mythology. Ed. by M. Hoppál \& J. Pentikäinen. To be publ. by Akad. Kiadó in 1987.

Reuterskiöld, E. 1910. Källskrifter till lapparnas mytologi. (Bidrag till vår odlings häfder 10.) Stockholm.

- 1927. Bevarade lapptrummor. Religionshistoriska studier tillägnade Edward Lehman 19.8.1927. Lund.

Reuterswärd, P. 1966. The Tessin-Cronström correspondence. Burlington Magazine.

Schefferus, J. 1956. Lappland. [Ed. by] E. Manker et al. (Acta Lapponica 8.) Lund. Shamanism in Eurasia. 1984. Ed. by M. Hoppál. Göttingen.

Shamanism in Siberia. 1978. Ed. by V. Diószegi \& M. Hoppál. Budapest.

Turi, J. 1910. Muittalus samid birra. [Ed. by] E. Demant. Stockholm.

Weinstein, S. I. 1984. Shamanism in Tuva at the turn of the 20th century. Shamanism in Eurasia. Ed. by M. Hoppál. Göttingen.

Weigert, R.-A. \& Hernmarck, C. 1964. L'Art en France et en Suède 1693-1718. Stockholm.

Wiklund, K. B. 1930. Olof Rudbeck d.ä. och lapptrummorna. Rudbeckstudier. Uppsala. 